\title{
Ekonomi Islam: Rasional dan Relevan
}

\author{
Oleh : Lely Shofa Imama*
}

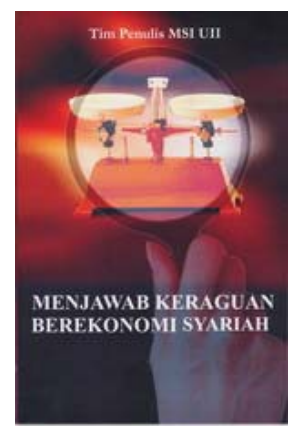

Judul : Menjawab Keraguan Berekonomi Syariah

Penulis : Tim Penulis MSI UII

Penerbit : MSI UII \& Safiria Insania Press

ISBN : : 979976617-6

Terbit : 2008

Tebal : 192 halaman + xiv (termasuk Index)

\section{Pendahuluan}

Dalam mengukur maju tidaknya, diterima tidaknya suatu sistem, terkadang kita hanya perlu memperhatikan beberapa aspek yang menjadi bagian dari sistem itu sendiri, tanpa harus mengupas dan mengkaji sistem tersebut secara eksklusif.

Demikian pula dengan sistem ekonomi Islam, yang diaku merupakan ekonomi berkeadilan, yang hadir sebagai alternatif pilihan masyarakat dalam menentukan pola berekonomi yang mengusung nilai keadilan, yang dapat diterapkan tanpa harus merugikan kelompok tertentu dan tidak berpihak pada kelompok tertentu.

Sebagaimana kita tahu, ekonomi konvensional yang merupakan pola berekonomi masyarakat sangat dipengaruhi oleh dua kelompok besar yang saling bertolak belakang dan tarik ulur dalam melihat dan memfungsikan indikator dan variable ekonomi, yaitu kapitalis dan sosialis. Namun beberapa tahun terakhir, sistem ekonomi Islam mulai dikenal dan dikembangkan di Indonesia. Minat dan kecenderungan masyarakat terhadap wacana ekonomi Islam cukup beragam, bahkan dapat dikatakan jika animo masyarakat terhadap jasa ekonomi Islam semakin hari semakin tinggi. Hal ini dapat dilihat dari semakin menjamurnya lembaga keuangan -bank maupun nonbank- berbasis syariah (wujud konkrit berikut ikon utama ekonomi Islam) dan antusiasme masyarakat dalam menggunakan jasa dari lembaga-lembaga tersebut.

* Mahasiswa MSI konsentrasi Ekonomi Islam angkatan 2006/2007, email: Lely_she@yahoo.com 
Di samping kelompok yang menyambut baik dan mendukung ekonomi Islam, tak dapat dipungkiri bahwa, akan selalu ada mereka yang cenderung pesimis dan mempertanyakan kembali esensi dan prospek penerapan ekonomi Islam dalam lini kehidupan masyarakat dewasa ini.

Saat ini, kita dihadapkan pada kenyataan bahwa minat masyarakat untuk berekonomi syariah walau menunjukkan progres positif, namun belum sesuai dengan harapan, bahkan dari kalangan akademisi, masih banyak yang mengindikasikan keraguan mereka akan relevansi dan akurasi ekonomi Islam untuk diterapkan.

Dalam menghadapi hal ini, yang mungkin perlu digaris bawahi untuk dipertanyakan adalah; mengapa banyak terjadi keengganan masyarakat untuk berekonomi syariah? Dan jawaban yang muncul tentunya cukup beragam, tergantung pada kapabelitas masing-masing individu dalam merespon pertanyaan ini. Namun semua jawaban tersebut mengerucut kepada satu hal yaitu metode dakwah.' Sehingga, dengan memperhatikan jawaban-jawaban yang menyeruak sedikit banyak akan membantu kita dalam menelusuri ulang dan mengemas metode dakwah yang sesuai untuk dipaparkan kepada masyarakat. Bahkan, tersirat semacam kesepakatan baku antar aktivis ekonomi syariah tentang metode dakwah yang dimaksudkan untuk meminimalkan kesimpang-siuran dan kesalahpahaman masyarakat mengenai ekonomi Islam. ${ }^{2}$

Upaya meluruskan dan memahamkan masyarakat akan urgensi ekonomi Islam tentunya tidak akan berfungsi sempurna apabila hanya dilakukan dalam tataran teoretis saja, akan tetapi perlu dibuktikan dalam bentuk visual, nyata, yang dapat disaksikan dan dirasakan manfaatnya oleh masyarakat sehingga semangat ekonomi Islam tidak terbatas pada ucapan belaka, namun terimplementasi secara nyata. Sehingga, pengukuhan bahwa agama Islam sebagai "rahmatan lil-'alamin" tidak hanya isapan jempol semata.

Berkenaan dengan hal ini, beberapa kalangan turut menyumbangkan ide dan hasil olah pikir mereka dalam memaparkan dan menjelaskan ihwal ekonomi Islam. Sebagai contoh, upaya tersebut dapat kita jumpai dalam buku yang diformat sebagai bungai rampai berjudul Menjawab Keraguan Berekonomi Syari'ah, yang merupakan hasil kolaborasi pemikiran tim penulis MSI UII. ${ }^{3}$

Dalam pengantar buku tersebut, Amir Mu'alim menyebutkan lima hal

${ }^{1}$ Dakwah dalam hal ini dipahami penulis sebagai upaya memahamkan setiap individu tentang intisari dan urgensi ekonomi Islam dan penerapan syari'ah dalam upaya mewujudkan keadilan sosial dalam masyarakat.

2 http://www.mail-archive.com/ekonomi-syariah@yahoogroups.com/msg03108. html, accessed on January, 20, 2009

${ }^{3}$ Menurut pengamatan penulis, upaya penulisan buku ini merupakan wujud semangat mengembangkan ekonomi Islam serta merupakan tuntutan intelektual bagi MSI UII karena salah satu konsentrasi bidang studi yang ditawarkan adalah ekonomi Islam. 
mendasar yang menjadi alasan penolakan/ pesimisme sebagian kalangan atas berlakunya sistem ekonomi Islam, antara lain: ${ }^{4}$

a. Anggapan bahwa ekonomi Islam muncul karena emosi agama semata.

b. Ketidaktahuan akan landasan dan filosofi penerapan ekonomi Islam pada tataran riil.

c. Ketidaktahuan akan perbedaan mendasar antara ekonomi Islam dan ekonomi konvensional yang merupakan keistimewaan ekonomi Islam.

d. Ketidaktahuan akan perhitungan matematis yang digunakan dalam penerapan ekonomi Islam.

e. Ketidaktahuan akan strategi pengembangan ekonomi Islam.

Lima hal di atas, tanpa menafikan faktor lainnya, menghasilkan beberapa pertanyaan, baik yang merupakan wujud keingintahuan maupun bentuk pesimisme akan diterapkannnya prinsip ekonomi Islam dalam kehidupan berekonomi masyarakat. Sehingga, ketika seorang individu maupun kalangan ingin menjawab pertanyaan yang muncul, maka ia sangat perlu melakukan pengkajian ulang mengenai apa yang ia paparkan -dalam hal ini ekonomi Islam-, dimulai dengan menelusuri sejarah muncul dan perkembangannya, mengupas sistem yang diberlakukan -baik secara teoretis maupun aplikatif-, untuk kemudian menelaah kembali relevansi dari penerapannya dan respon masyarakat terhadapnya, sehingga fungsi dan dampak dari sistem tersebut dapat dinikmati secara nyata, tak sekedar teori yang hanya berlaku sebatas kajian tanpa ada sumbangsih praktis, baik bagi individu maupun masyarakat secara umum.

\section{Ekonomi Islam; Sejarah dan Karakteristik}

Ekonomi Islam merupakan salah satu bentuk realisasi visi agama Islam, yaitu sebagai agama yang mengusung fungsinya sebagai rahmatan lil-'alamin, agama kebaikan dan kesejahteraan. ekonomi Islam yang berlandaskan pada tauhid menekankan bahwa segala sesuatu hanyalah milik sang Pencipta, sehingga unsur keserakahan tidak terpupuk dan mempengaruhi perilaku manusia sebagai pelaku ekonomi.

Ekonomi Islam telah ada semenjak Islam bermula. Melalui praktik sosial yang dicontohkan oleh Muhammad SAW. Selaku pengemban risalah Islam, setiap muslim dapat melihat gambaran bagaimana Islam memberikan tuntunan mengenai interaksi antar sesama manusia.

Dalam tataran keilmuan, ekonomi Islam telah dikaji dan dikembangkan secara informal, baik oleh kalangan akademisi maupun profesional, baik mengupas ekonomi Islam secara eksklusif maupun inklusif -memadukan kajian ekonomi

${ }^{4}$ Tim Penulis MSI UII (2008), Menjawab Keraguan Berekonomi Syariah, (Yogyakarta: MSI UII-Safiria Insania Press), hal. xii.

${ }^{5}$ Ibid, hal. 2-3. 
Islam dengan kajian sejarah dan studi keislaman misalnya-.

Berikut ini merupakan empat tahapan perkembangan dalam wacana pemikiran ekonomi Islam menurut Khurshid Ahmad, bapak ekonomi Islam, sebagai mana ditulis oleh Nur Kholis, salah seorang kontributor buku Menjawab Keraguan Berekonomi Syariah, ${ }^{6}$

a. Pertama, masa di mana sebagian ulama, yang meskipun tidak memiliki pendidikan formal dalam bidang ekonomi namun memiliki pemahaman terhadap persoalan-persoalan sosio-ekonomi pada masa itu, mencoba menuntaskan persoalan bunga. Tahapan ini ditandai dengan mulai didirikannya bank islam -walau terbatas dalam skala lokal- yang tidak berdasarkan sistem bunga. Masa ini dimulai pada pertengahan dekade 1930an dan berjaya pada akhir 1950-an dan awal 1960-an.

b. Kedua, di mulai pada akhir dasa warsa 1960-an, di mana para ekonom muslim yang pada umumnya belajar di perguruan tinggi terkemuka di Amerika dan Eropa mulai mencoba mengembangkan aspek-aspek tertentu dari sistem moneter Islam. Mereka melakukan analisis ekonomi terhadap larangan riba -dalam hal ini bunga- dan mengajukan alternatif perbankan tanpa bunga. Tahapan ini ditandai dengan mulai maraknya seminar dan konferensi internasional tentang ekonomi dan keuangan Islam yang mengundang para pakar, ulama, dan ekonom, baik muslim maupun non-muslim.

c. Ketiga, ditandai dengan upaya-upaya konkrit untuk mengembangkan perbankan dan lembaga-lembaga keuangan non-riba, yang merupakan sinergi antara usaha intelektual dan material para ekonom, pakar, pengusaha, dan hartawan muslim yang peduli pada perkembangan ekonomi Islam. Pada tahapan ini mulai berdiri bank Islam standar internasional.

d. Keempat, pengembangan pendekatan ekonomi Islam lebih integratif dan sophisticated dalam membangun keseluruhan teori dan praktek ekonomi Islam, terutama lembaga keuangan dan perbankan yang merupakan indikator ekonomi umat.

Adapun karakteristik ekonomi Islam, dapat kita pahami dari prinsip-prinsip dasar ekonomi menurut Umer Chapra,

a. Prinsip Tauhid, yang merupakan pondasi keislaman dalam Islam, yang menekankan bahwa segala sesuatu yang diciptakan oleh Allah SWT. bukan sia-sia akan tetapi memiliki tujuan, di mana tujuan tersebut memberikan signifikansi dan makna pada eksistensi jagat raya, termasuk manusia sebagai penghuninya.

b. Prisip Khilafah, yang mengingatkan status manusia sebagai khalifah di bumi Allah SWT., sehingga dapat berperan efektif dalam menjaga dan

${ }^{6}$ Ibid, hal. 54-56.

${ }^{7}$ M. Umer Chapra (2001), Masa Depan Ilmu Ekonomi, (terj.) Ikhwan Abidin, The Future of economics: An Islamic Perspective, hal. 202-206 dalam Ibid, hal. 57. 
melestarikan apa yang telah Dia ciptakan. Implikasi dari prinsip ini antara lain: persaudaraan universal, sumber daya adalah amanah, gaya hidup sederhana, dan kebebasan manusia.

c. Prinsip keadilan, yang merupakan salah satu misi agama Islam, yang berimplikasi pada pemenuhan kebutuhan pokok manusia, sumber-sumber pendapatan yang baik, distribusi kekayaan yang merata, serta pertumbuhan dan stabilitas.

\section{Ekonomi Islam; Teori dan Praktek}

Seiring perkembangan zaman dan pengetahuan, pola hidup manusia sedikit banyak mengalami perubahan, yang berpengaruh pada aturan yang dijadikan standar norma dan etika bersosial masyarakat. Hal ini berlaku karena secara teori, segala bentuk perilaku dalam Islam berikut perubahannya harus memiliki status hukum yang jelas, karena dalam Islam, segala sesuatu tak lepas dari pengawasan syari'at (dalam hal ini pembuat syari'at; Allah SWT.). ${ }^{8}$

Oleh karena itu, Islam memberikan landasan pokok untuk dapat dikembangkan dan diterapkan sesuai masa dan kondisi yang dijalani oleh manusia, yaitu ijtihad berkenaan dengan pemahaman atas al-Qur'an dan hadits. Adapun pemahaman dan penerapannya, harus selalu disesuaikan dengan indikasi yang berlaku, sehingga relevansi pokok agama tetap berlaku. ${ }^{9}$

Pada prinsipnya, hukum awal segala sesuatu -termasuk dalam bidang mu'amalat/ transaksi- adalah mubah, yang dapat dipahami sebagai penundaan status hukum terhadap fenomena yang baru dan akan muncul sehingga dilakukan kajian intensif dan mendalam untuk dapat diputuskan hukumnya, baik wajibmandub-makuh-haram, maupun kembali pada hukum asalnya yaitu mubah (boleh dan netral, tidak condong pada salah satu hukum yang empat). Mubah sebagai konsep adalah hukum yang paling membutuhkan kejelasan yang sejalan dengan penegasan mengenai keharusan untuk melakukan adaptasi dan juga untuk merespon perubahan kehidupan sehingga selalu ditemukan relevansinya. ${ }^{10}$

Secara konseptual, sebagai sebuah sistem, ekonomi Islam merupakan bagian dari tata kehidupan yang lengkap berdasarkan empat bagian nyata dari pengetahuan yaitu; yang diwahyukan (al-Qur'an), tauladan Nabi (sunah), deduksi analogik (qiyas), dan penafsiran masyarakat berdasrakan kesepakatan para ulama (Ijma'). Sehingga, dalam penerapannya, ekonomi Islam tidak bisa terlepas dari

${ }^{8}$ Ibid, hal. 143 .

9 Upaya memahami dan menerapkan yang dimaksud adalah proses ijtihad, tentunya yang bersifat obyektif, Muhammad Baqir ash-Shadr (2008), Buku Induk Ekonomi Islam: Iqtisâdunâ, (terj.) Yudi, Our Economics, (Jakarta: Zahra), hal. 111-112.

${ }^{10}$ Tim Penulis MSI UII (2008), hal. 156-157. 
keempat hal di atas. ${ }^{11}$

Dalam aplikasinya, praktik ekonomi Islam terimplementasi dalam lembaga keuangan dan perbankan berbasis syari'ah yang tidak menjadikan bunga sebagai salah satu aset transaksi, lembaga pengelolaan zakat, dan praktik bisnis Islami. Pun diadakannya kajian ekonomi Islam, baik formal maupun nonformal untuk menghindari simbolisasi syariah semata karena pelaku di dalamnya tidak memahami landasan, filosofi dan aturan yang berlaku.

Pengembangan ekonomi Islam di bidang akademik dapat kita lihat dengan dibukanya program studi khusus di beberapa perguruan tinggi berkenaan dengan ekonomi Islam. Upaya ini tentunya bertujuan untuk menghasilkan tenaga ahli yang diharapkan mampu mengembangkan sistem ekonomi Islam di masa mendatang baik secara konseptual maupun penerapannya di dunia kerja. ${ }^{12}$

\section{Relevansi dan Prospek Ekonomi Islam}

Sistem ekonomzi Indonesia berorientasi kepada sistem ekonomi campuran, sebuah sistem ekonomi yang biasa digunakan oleh negara berkembang. Kebijakan ekonomi Indonesia berdasarkan sistem ekonomi campuran masih mengarah kepada sistem atau kebijakan ekonomi kapitalis yang terbukti hanya memberikan dampak negatif bagi perekonomian suatu negara. Sudah dapat ditebak, situasi perekonomian Indonesia menjadi kurang kondusif karena kebijakan-kebijakan ekonomi yang dinilai kurang tepat dengan situasi perekonomian Indonesia saat ini. $^{13}$

Secara garis besar, sistem ekonomi di Indonesia berlandaskan pada Pancasila dan UUD 1945 mengandung nilai yang sama dengan nilai-nilai yang terdapat pada sistem ekonomi Islam yang berlandaskan pada al-Quran dan hadits Rasulullah Muhammad SAW. Persamaan nilai tersebut adalah usaha untuk mencapai nilai keadilan dalam bidang ekonomi untuk setiap individu baik dengan menggunakan sistem ekonomi Indonesia yang berlandaskan Pancasila dan UUD 1945 maupun dengan menggunakan sistem ekonomi Islam, ${ }^{14}$ sehingga relevansi ekonomi Islam untuk diterapkan tidak perlu dipertanyakan kembali.

Adapun prospek ekonomi Islam, dapat dikatakan bahwa faktor kunci sukses ekonomi, termasuk dalam dunia perbankan, adalah inovasi produk yang mengedepankan aspek keadilan dan mampu merespon kebutuhan finansial yang

${ }^{11}$ Ibid, hal. 122 .

${ }^{12}$ Ibid.

13 http://smadangawi.top-forum.net/bisnis-and-enterpreneurship-f4/pandanganterhadap-kebijakan-ekonomi-indonesia-ditinjau-dari-konsep-dasar-ekonomi-islamt218.htm, accessed on January, 20, 2009.

14 http://smadangawi.top-forum.net/bisnis-and-enterpreneurship-f4/pandanganterhadap-kebijakan-ekonomi-indonesia-ditinjau-dari-konsep-dasar-ekonomi-islamt218.htm, accessed on January, 20, 2009. 
sesuai dengan standar pola berekonomi masyarakat secara umum. ${ }^{15}$

Sebagai contoh, sistem operasional bank syariah mempunyai warna dan keunikan tersendiri yang memungkinkan para nasabah penyertaan (shâhibulmâl, khususnya deposan) untuk memilih bentuk akad dan sektor tertentu dalam mengalokasikan dana yang dimilikinya. ${ }^{16}$ Selain itu, diberlakukannya UU perbankan syari'ah No. 21 tahun 2008 sebagai landasan hukum praktik bank syari'ah cukup membantu dan menjamin eksistensi ekonomi Islam di Indonesia.

\section{Penutup}

Masalah ekonomi senantiasa menarik perhatian berbagai macam lapisan masyarakat dan individu. Berbagai penelitian telah dibuat untuk menyelesaikan permasalahan ekonomi tersebut. Walaupun begitu, usaha mencari penyelesaian yang tepat dan akurat dalam mengatasi masalah ini secara keseluruhan menemui kegagalan yang berujung pada krisis ekonomi.

Dari berbagai sistem ekonomi yang ada, dengan segala kelebihan dan kekurangan yang dimiliki, sistem ekonomi Islam dianggap sebagai smart solution dari berbagai sistem ekonomi yang ada karena secara etimologi maupun secara empiris, terbukti sistem ekonomi Islam menjadi sistem ekonomi yang mampu memberikan kemakmuran dan kesejahteraan yang nyata dalam penerapannya pada saat zaman Rasulullah Muhammad SAW dan pada masa khulafa' rasyidun karena sistem ekonomi Islam adalah sistem ekonomi yang berdasarkan pada nilai keadilan dan kejujuran yang merupakan refleksi dari hubungan vertikal antara manusia dengan Allah SWT. ${ }^{17}$

Sistem ekonomi Islam mengajak para pelakunya untuk lebih peduli kepada sesama manusia sebagai salah satu sarana dalam mencapai keselamatan dunia dan akhirat, sebagaimana tersirat pada tidak membenarkan praktik-praktik ribawi seperti pada sistem ekonomi kapitalis karena riba dapat mendzalimi sesama manusia. ${ }^{18}$

Dengan diberlakukannya ekonomi Islam di Indonesia, dalam hal ini dapat kita lihat di dunia perbankan kita sebagai indikator utama ekonomi Islam, diharapkan ekonomi berkeadilan yang menjadi tujuan ekonomi Islam dapat menjadi nyata. Hal ini karena ekonomi Islam hadir sebagai solusi dan telah

${ }^{15}$ Mervyn K. Lewis dan Latifa M. Algaoud (2007), Perbankan Syariah, (terj.) Burhan Subrata, Islamic Banking, (Jakarta: PT. Serambi Ilmu Semesta), hal. 273.

${ }^{16}$ Tim Penulis MSI UII (2008), hal. 117.

17 http://smadangawi.top-forum.net/bisnis-and-enterpreneurship-f4/pandanganterhadap-kebijakan-ekonomi-indonesia-ditinjau-dari-konsep-dasar-ekonomi-islamt218.htm, accessed on January, 20, 2009.

${ }^{18} \mathrm{http}: / /$ isefunsri.wordpress.com/2008/09/10/mahasiswa-ekonomi-islam/, accessed on January, 20, 2009. 
terbukti rasionalitasnya; baik secara nilai, akademik, maupun praktis. ${ }^{19}$

Setelah membaca buku ini (reviewed), secara umum, penulis mendapatkan pencerahan dalam memahami ekonomi Islam. Sebagaimana bunga rampai pada umumnya, sangat wajar apabila terdapat multi interpretasi dalam penyajian masing-masing topik. Akan tetapi, untuk ke depannya perlu ditelaah kembali agar tidak terjadi tumpang tindih dalam pembahasan, ${ }^{20}$ sehingga tema yang disajikan dapat lebih fokus dan dipahami secara maksimal.

Selain pengulangan informasi, yang tentunya me-mubazir-kan masa, kerancuan dalam penggunaan istilah juga perlu menjadi perhatian. Hal ini tak lain disebabkan karena menurut hemat penulis, pembaca ibarat murid yang mengais ilmu dari para kontributor, sehingga sangat mungkin apabila istilah yang rancu dapat menimbulkan kesalahpahaman dan salah pemaknaan dari pembaca. ${ }^{21}$

Di samping itu, dalam membaca sejarah, obyektifitas sangat diperlukan sehingga bias kecondongan terhadap sesuatu dan antipati terhadap sesuatu yang lain dapat dihindari. Demikian pula dalam mengkaji sebuah sistem. Terkadang sistem yang kita anggap salah kaprah memang memiliki kekurangan dan mengandung unsur ketidakadilan, namun hal itu tidak berarti kita boleh menjustifikasi sistem tersebut sebagai sistem yang harus dihindari dan pantang untuk dikaji.

Sebagai contoh, sistem ekonomi konvensional yang seringkali kita sebut sebagai sistem ekonomi ribawi, jauh dari unsur keadilan. Hal ini bukanlah legitimasi bagi kita untuk dapat menghujat sistem tersebut, akan tetapi akan lebih baik jika sistem tersebut kita kaji ulang, cari celah kelemahannya untuk kemudian kita sesuaikan dengan landasan keadilan yang kita pahami, karena kesalahan ekonomi konvensional terletak pada sistem dan ideologinya, bukan pada alat bantu yang digunakan dalam sistem tersebut. Dalam hal ini, kajian mengenai ekonomi konvensional juga sangat diperlukan dalam upaya mencari titik tengah yang solutif, tanpa menafikan realitas bahwa dari mengkaji sistem ekonomi konvensional itulah kita dapat menemukan format ekonomi Islam yang sesuai dengan pola berekonomi masyarakat sekarang, dengan tetap berpegang teguh pada norma keislaman yang mengusung aspek keadilan, sehingga simbolisasi syari'ah an-sich dapat kita hindari.

Secara keseluruhan, buku Menjawab Keraguan berekonomi Syari'ah sangat penting untuk dibaca oleh semua peminat dan pemerhati ekonomi Islam, baik kalangan akademisi, praktisi, maupun awam, setidaknya untuk meluruskan

${ }^{19}$ Tim Penulis UII (2008), hal. 31-37.

${ }^{20}$ Sebagai contoh, adanya tumpang tindih pembahasan antara Bab I dan Bab III.

21 Dalam membaca, seringkali penulis menemukan istilah yang saling bertolak belakang dan kurang pada tempatnya. Sebagai contoh, penggunaan "tas" dan "isme" serta kesalahan eja dalam penulisan sehingga menimbulkan makna yang jauh dari konteks. Selain itu, kutipan yang tidak diakui sebagai kutipan asli akan tetapi tidk disebutkan sumbernya. 
pandangan keliru atas hadir dan berkembangnya ekonomi Islam dalam sistem perekonomian kita. Tulisan ini tidak berarti apa-apa, namun penulis berharap dapat menjadi stimulant bagi para pembaca untuk mengkaji buku yang dibahas secara tuntas. Selamat membaca!

\section{DAFTAR PUSTAKA}

Ash-Shadr, Muhammad Baqir, (2008), Buku Induk Ekonomi Islam: Iqtisâdunâ, (terj.) Yudi, Our Economics, Jakarta: Zahra.

Lewis, Mervyn K. dan Latifa M. Algaoud (2007), Perbankan Syariah, (terj.) Burhan Subrata, Islamic Banking, Jakarta: PT. Serambi Ilmu Semesta.

Tim Penulis MSI UII (2008), Menjawab Keraguan Berekonomi Syariah, Yogyakarta: MSI UII-Safiria Insania Press.

http://isefunsri.wordpress.com/2008/09/10/mahasiswa-ekonomi-islam/

http://www.mail-archive.com/ekonomi-syariah@yahoogroups.com/msg03108. $\underline{\mathrm{html}}$

http://smadangawi.top-forum.net/bisnis-and-enterpreneurship-f4/pandanganterhadap-kebijakan-ekonomi-indonesia-ditinjau-dari-konsep-dasarekonomi-islam-t218.htm 